Original Research

\title{
Simulating Soil Organic Carbon Dynamics under Climate Change Scenarios in an Arid Ecosystem
}

\author{
Farhad Derakhshan, Nourollah Abdi*, Hamid Toranjzar, Abbas Ahmadi \\ Department of Range and Watershed Management, Arak Branch, Islamic Azad University, Arak, Iran
}

Received: 17 April 2020

Accepted: 29 June 2020

\begin{abstract}
Land use change and climate have significant effects on decomposition of soil's organic carbon and ultimately carbon dioxide $\left(\mathrm{CO}_{2}\right)$ emissions from the soil into the atmosphere. The Rothamsted carbon model is one of the most widely used models in studies related to soil carbon sequestration which is applied in many studies to investigate the effect of climate change on soil carbon storage. The purpose of the present study is to investigate the effect of land uses of native rangeland, restoration rangeland, cattle-grazed rangeland, agro-ecosystem, as well as simulating the effect of two climate scenarios on soil carbon storage using the Roth $\mathrm{C}$ model on the four mentioned type of lands in the Markazi Province, Iran for 33 years (2017-2050). In this study, 102 soil samples were taken to determine soil organic carbon and other soil characteristics and SOC stock were calculated at a depth of 0-30 cm in each land use. The results showed that due to the restoration rangeland, after 8 years, there was a significant increase in SOC stock (17.76\%), and after 17 years, in farm use, there was a (3.47\%) decrease in the amount of SOC stock compared to the local rangeland of the area (control rangeland) in the Markazi Province, Iran. The simulation results of RothC model also showed that SOC stock in 2050 in treatment of the local, the restoration, the cattle-grazed and the cultivated rangelands and also due to the climate change will decrease $6.28 \%, 16.09 \%, 13.12 \%$, and $7.28 \%$, respectively.
\end{abstract}

Keywords: soil carbon sequestration, Soil Organic Carbon, global warming, rangeland restoration, native rangeland

\section{Introduction}

Soil plays a crucial role in the life of our planet. The chemical and biological processes that take place in soil regulate the geochemical cycles of most

*e-mail: nabdi1355@yahoo.com chemical elements, making soil a kind of a buffer and a groundwater "filter" [1]. Soil exchange issues affect the amount of nutrients; hence, the type and quality of soil affect ecosystem productivity [2]. In the soil ecosystem, soil organic carbon (SOC) influences soil physical and chemical processes, and serves as a source of plant nutrients. The storage of organic carbon in the soil depends on the balance between gains and losses of $\mathrm{C}$. Biotic characteristics such as biomass production 
and microbial abundance, mean annual precipitation and temperature, soil characteristics including texture, lithology and anthropogenic activities, like land use and management, influence the processes of SOC storage or losses. A clear description of the distribution and changes of SOC and its factors of control will help predict the consequences of climate change [3]. The future projection indicates to increase in precipitation amounts in the rainy and winter season and diminishes in summer season under all future scenarios. The seasonal temperature changes analysis for all areas, the future temperature are predicted to steadily increase with higher rates during summer than the other two seasons [4].

The dominant vegetation type in each ecosystem is one of the factors affecting SOC stock [5]. By converting native vegetation to other vegetation, the biogeochemistry of carbon stored in soils is significantly altered, releasing carbon stored in biomass, increasing the rate of soil carbon decomposition, and ultimately reducing the level of organic carbon. Various uses and vegetation will alter the flow of energy, carbon and nutrients as well as vertical and horizontal movement of water, resulting in soil fertility and soil organic carbon content [6].

SOC tends to decrease when transforming rangelands, forest or other native ecosystems to croplands and to increase when restoring native vegetation on former croplands or by restoring organic soils to their native condition. The effects of land use and land cover change (LULCC) have become a key issue for the scientific community concerned with global environmental change. Human-induced LULCCs have contributed to soil degradation and soil loss, leading to a decrease in soil $\mathrm{C}$ storage worldwide, more intensely during the last decades in the Mediterranean areas [7]. It is known that land use changes affect SOC stocks. While undergoing natural or human-affected changes, an ecosystem can work as a carbon sink or source, depending on the direction of the conversion. This problem is important and widely discussed in the context of soil degradation, as well as $\mathrm{CO}_{2}$ emissions and from a purely academic point of view [8-9]. Many studies have focused on SOC distribution in the biologically active layers of topsoil, where SOC and nutrient cycling is most dynamic [10].

Climate change has a major impact on soil properties and processes, including SOC storage. Organic matter, considered one of the primary indicators of soil quality in agriculture and the environment, is reduced as a result of climate change and global warming [1112]. During the last few decades, land use changes have largely affected the global warming process through emissions of $\mathrm{CO}_{2}$. However, $\mathrm{C}$ sequestration in terrestrial ecosystems could contribute to the decrease in atmospheric $\mathrm{CO}_{2}$ rates [13].

Climate change was found to be an important driver of change in forest SOC over the $21^{\text {st }}$ century, projected forest management and land-use change will have greater effects, leading to only small losses or increasing European forest SOC stocks. According to the same study climate change may cause loss of SOC for most areas in Europe. This decline could be reversed if adaptation measures in the agricultural sector to enhance soil carbon were implemented. It should be noted that these modeled projected changes are very uncertain [14].

Most of the known factors acting on SOC dynamics have been implemented in simulation models which take into account the interactions among climate, pedology, cropping system, soils and crop management [15]. Moreover, well validated models can be used to predict SOC changes under different management and climatic conditions that may occur in the future [16]. Among SOC models, CENTURY [17] and RothC [18] are particularly suitable to describe the turnover of the different SOC pools. Both models have been extensively applied worldwide under a variety of pedoclimatic and cropping conditions, and have a similar structure, containing pools with a rapid turnover (month-year), moderate turnover (decadal), and slow turnover (millennial or inert). The first model is more complex and requires a high number of input parameters, while the second requires a low number of parameters easy to be collected, but it only simulates processes in the topsoil layer (e.g., 20-25 cm) [10]. RothC-26.3 is a model of the turnover of organic carbon in nonwaterlogged soils that allows for the effects of soil type, temperature, moisture content and plant cover on the turnover process [19].

The average annual temperature rise in different areas of Iran in the year 2050 was in the range of 3.5 to 4.4 , and the increase in temperature from west to east and north to south [20]. Based on the above rangeland restoration and native rangeland background, we investigated the changes SOC in grassland soil under different restoration measures in the Ghal-Cheshmeh region. Therefore, the objectives of this study were: (1) to evaluate the performance of RothC model using SOC data measured in 2017 from four different vegetation covers; (2) to assess the impacts of present climate and climate change scenarios on SOC dynamics from soil; and (3) to assess SOC stock in rangelands and agro-ecosystems in an arid ecosystem.

\section{Materials and Methods}

\section{Research Area and Data Sources}

The Gal-Cheshmeh rangeland includes an area of about 31000 hectares and is located in southwest of Mahallat $\left(33^{\circ} 43^{\prime} \mathrm{N}, 50^{\circ} 32^{\prime} \mathrm{E}\right)$ in central Iran (Markazi Province) (Fig. 1). The minimum altitude is 1550 meters above sea level and maximum altitude is 2300 meters above sea level. Based on 30 years of statistics (1975 to 2017), the Mahallat Synoptic Weather Station has an annual rainfall average of $251.1 \mathrm{~mm}$ and an annual 
temperature average of $15.9^{\circ} \mathrm{C}$ and the evaporation rate from evaporation pan is $2091.74 \mathrm{~mm}$ (Table 1). After preliminary identification and determination of the area boundaries, with regards to the purpose of the study, four lands with rangeland and agricultural uses were selected in the study region. Land uses included: native rangelands (control), rangelands under extreme cattlegrazing, restored and enclosed rangelands and agroecosystem (Fig. 1).

Rangelands ecosystems had plant types of such as of Artemisia siberi - Scariola orientalis - Astragalus gossypinus control rangelands were under moderate grazing. In 2011, restoration rangelands were cultivated using species such as, Zygophyiium atriplicoides, Amygdalus scoparia, and Atriplex canesence, but were enclosed for 8 years. Agro-ecosystems included annual crop fields (wheat and barley) alternating with cucurbits cultivation (tomato and pumpkin cultivation), fallow lands, and Rosa damascena cultivation. This ecosystem is located in the vicinity of rangelands in the region, it was among the rangelands of the region before 2000, which has gone through land use change. Cultivation of Rosa damascena shrub has been part of the agricultural use since 2014. Irrigation and fertilization treatments (chemical and animal) are used in the agro-ecosystem.

A systematic random sampling method was used, so that in each rangeland plant type or agricultural land use, 3 transects with 50 meters of length and along each transect, four $2 \times 2$ plots with random intervals, are used. Species composition and percentage of vegetation (canopy density) were determined in each plot. To measure aerial biomass, a section of biomass was cut and weighed and based on this, total fresh-weight of aerial biomass of each plot was determined. To determine root biomass of dominant rangeland plants (Artemisia sieberi, Astragalus gossypinus, herbaceous plants, Atriplex canesence, Zygophyiium atriplicoides and Amygdalus scoparia) and agricultual plants (Hordeum vulgaris and Rosa damascena), for each dominant plant at least three samples with small, large and medium sizes were exracted by direct excavation of the soil around the roots and extracting as much of the roots as possible. Evidence from the region (such as the root of species in the trenches located in the area of the plot) was also used to increase the accuracy of determining root biomass to aerial biomass ratios.
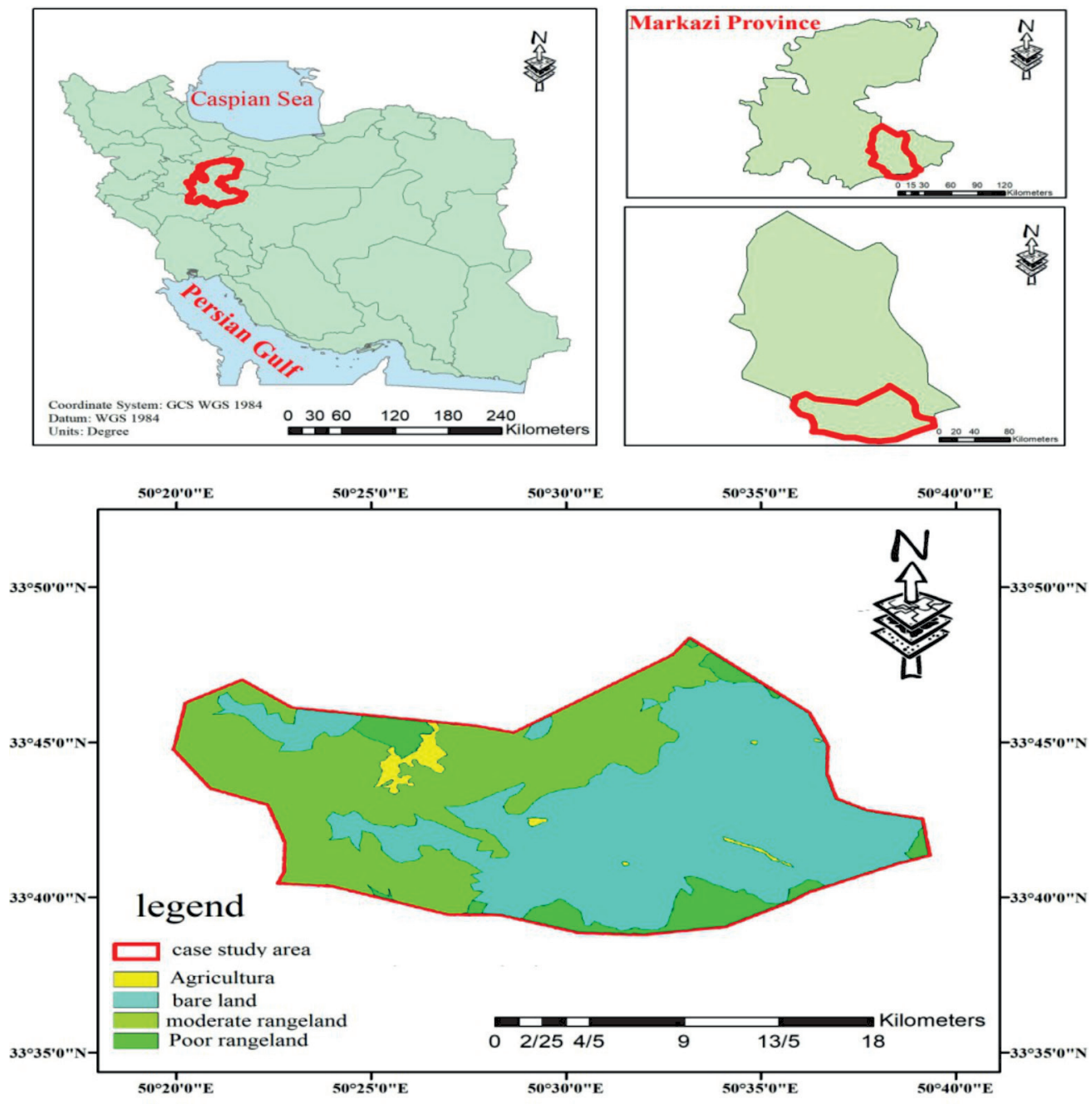

Fig. 1. Location of the study area (Markazi Province, Iran). 
To determine the percentage of aerial and root biomass dry matter, part of the fresh biomass of dominant plants was weighed, recorded and put in paper envelope and sent to the laboratory and finally placed in oven (temperature $75^{\circ} \mathrm{C}$ ) and after weight fixation, dry matter percentage of samples were determined. To determine the amount of litter in the plots, depending on the available amount of litter, the whole litter in the plot was collected and weighed or a part of it (at least 1/4) was collected and weighed and based on that the total litter in the plot was determined. Soil samples were taken from the center of each transect at a depth of 0 to $30 \mathrm{~cm}$. A total of 102 plots were evaluated from rangeland and agricultural work units. In the laboratory, the soil texture was established using BOUYOUCOS DENSIMETER method which is based on the changes of specific weight (weight per unit volume) of soil and water mixture during deposition. In the laboratory, the soil texture was established using BOUYOUCOS DENSIMETER method which is based on the changes of specific weight (weight per unit volume) of soil and water mixture during deposition. Soil bulk density was determined by soli mass method (in grams per cubic centimeter). Soil acidity was measured by potentiometric method using an electronic $\mathrm{pH}$ meter. Soil electrical conductivity was determined using an electronic EC meter. Soil organic carbon content (SOC) was determined by the Walkley-Black method. Finally SOC stock at $0-30 \mathrm{~cm}$ depth was calculated using the following equation [21]:

$$
\begin{aligned}
& \text { SOC stock }=\text { SOC content }(\%) \times \text { Layer } \\
& \text { thickness }(\mathrm{cm}) \times \text { bulk density }\left(\mathrm{g} \mathrm{cm}^{-3}\right)
\end{aligned}
$$

\section{Description of the Rothamsted Carbon Model}

The Roth $\mathrm{C}$ model is a simple model suitable for long-term simulation of soil organic carbon and $\mathrm{CO}_{2}$ emission from the soil to the atmosphere because it requires limited data [18]. This model divides soil organic carbon into four active components and one inactive component. Active components of soil organic matter include decomposable plant material, resistant plant material, microbial biomass, and mummified organic matter. In this model, the inactive component is a proportion of organic matter that is not biologically active and has a radiocarbon age of more than 50,000 years and is therefore not involved in the carbon cycle [22]. The Roth $\mathrm{C}$ model classifies plant litter entered into the soil, based on the ratio of decomposable plant material to resistant plant material (litter quality) into RPM and DPM reservoirs and then plant material are decomposed in the form of $\mathrm{CO}_{2}$, microbial biomass and mummified organic matter. In the present study, Roth $\mathrm{C}$ model version 26.3 was used to simulate the effect of climate on SOC stock [18]. The input data fed into the Roth $\mathrm{C}$ model in two main files (meteorological and management), each containing a set of variables (Fig. 2).

\section{Initial Valuation and Model Calibration}

Initial evaluation of the model involves entering the required soil data, vegetation and area climate information into the model. The data include, mean monthly precipitation, mean monthly temperature and mean monthly evaporation were obtained from the local synoptic meteorological station. Site-specific parameters, including soil and vegetation data, were acquired from field and laboratory measurements (Tables 1 and 2). Quality factor of plant residues (ratio of decomposable plant material to resistant plant material) for natural of rangeland, restoration rangeland, cattle-grazed rangeland and cultivated rangeland were chosen $0.67,0.67,0.67,1.44$, respectively (Tables 1 and 2).

The model baseline was established by the control rangeland treatment as native vegetation of the area, meaning that the amount of soil carbon in the natural rangelands of Gal-Cheshmeh was considered as the main and native carbon content of the area. Model was implemented in rangelands treatment in September 2017 (Table 1); based on knowing the initial total SOC content, clay content, climate conditions, soil surface cover, as well as the amount of inert organic matter in the $30 \mathrm{~cm}$ depth of soil [18, 23, 24], using equation (2), which is calculated on the basis of total organic carbon of the soil [25].

$$
\mathrm{IOM}=0.049(\text { total SOC })^{(1.139)}
$$

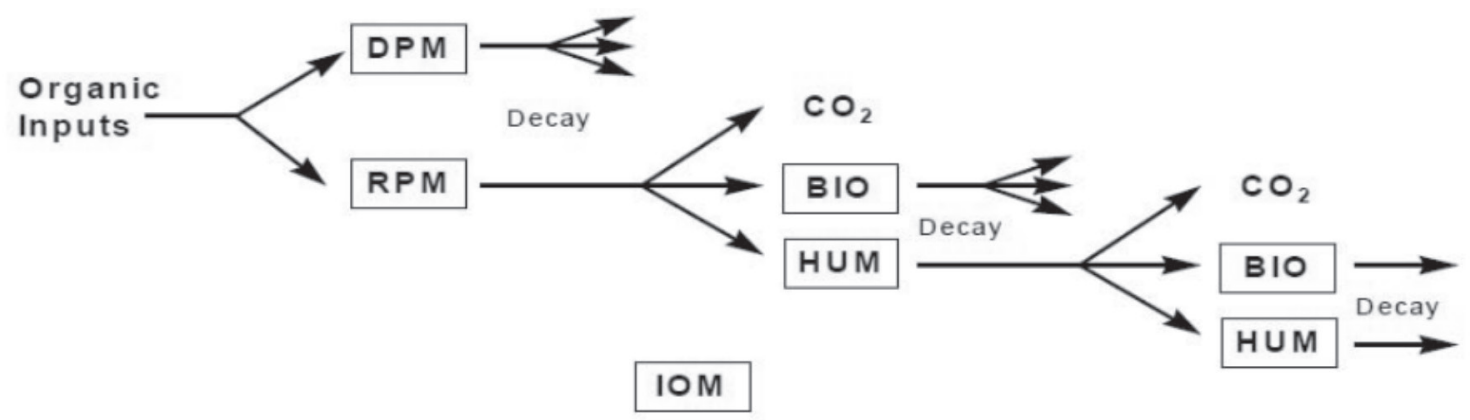

Fig. 2. The Roth C model Structure. 
Table 1. Soil and vegetation characteristics and climatic parameters in native vegetation (rangeland).

\begin{tabular}{|c|c|}
\hline (Parameter) & (Value) \\
\hline Average annual precipitation $(\mathrm{mm})$ & 239.40 \\
\hline Average annual temperature $\left({ }^{\circ} \mathrm{C}\right)$ & 15.9 \\
\hline Total open pan evaporation $(\mathrm{mm})$ & 2091.74 \\
\hline Texture (sand, silt, clay $\left.{ }^{*}\right) \%$ & $14.68 \%, 21 \%, 64.32^{*} \%$ \\
\hline Bulk density $\left(\mathrm{gr} \mathrm{cm}^{-3}\right)^{*}$ & 1.836 \\
\hline $\mathrm{pH}$ & 7.45 \\
\hline Initial total SOC $\left(\text { Ton ha }^{-1}\right)^{*}$ & 58.64 \\
\hline Soil depth $\left(\mathrm{cm}^{*}\right.$ & 30 \\
\hline Inert Organic Matter $\left(\mathrm{Ton} \mathrm{ha}^{-1}\right)^{*}$ & 2.18 \\
\hline DPM/RPM & 0.67 \\
\hline Soil carbon inputs $\left(\text { Ton C ha }^{-1}\right)^{\mathrm{a}}$ & 2.85 \\
\hline
\end{tabular}

The variables specified with * required inputs are The Rothamsted model.

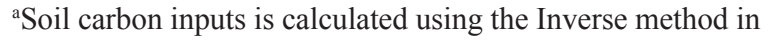
the RothC model based on knowing the total amount of soil organic carbon in an area with specific climate characteristics for vegetation.

Model calibration was performed by running the model for climate and soil conditions in rangeland treatment for 10000 years in equilibrium state with the end point in September 2017. The model was repeatedly run and model outputs were visited at each run and plant carbon inputs were repeatedly adjusted so that the amount of measured SOC stock becomes equal with simulated SOC stock in rangeland treatment in September 2017 [15]. In rangeland treatment, 2.8512 (Ton $\mathrm{C} \mathrm{ha}^{-1}$ ) as input carbon to soil through litter return was required, for SOC stock to reach 58.644 (Ton $\mathrm{C} \mathrm{ha}{ }^{-1}$ ) at $30 \mathrm{~cm}$ depth in September 2017 (Table 1). With maintaining the equilibrium state in this method, other files were created for native vegetation (rangeland treatment) to simulate changes in the effects of other plant treatments. By maintaining equilibrium state of the native rangeland coverage until 2011, Atriplex canesence, Zygophyiium atriplicoides and Amygdalus scoparia were cultivated in 2011 and it was assumed that Atriplex canesnce, Zygophyiium atriplicoides, and Amygdalus scoparia had a carbon input of 3.2015 tons of carbon per hectare into the soil (Table 2). Another part of Gal-Cheshmeh area with maintaining the equilibrium state under natural rangeland cover untill 2014, cultivation of barley alternating with cucurbits and fallow land since 2000 and Rosa damascena in 2014 were cultivated in agricultural lands. It was assumed that the cultivated rangeland treatment of has an input carbon to the soil of 2.7640 (Ton $\mathrm{C} \mathrm{ha}^{-1}$ ). Also in another part in the Gal-Cheshmeh area, maintaining equilibrium state under native rangeland coverage until 2014, grazing rangeland without any rangeland management and executive operations, it was assumed that the treatment of grazing rangelands has an input of $2.0050\left(\right.$ Ton $\left.\mathrm{C}_{\text {ha }}^{-1}\right)$ (Table 2).

\section{Climate Change Scenarios}

In the present study, the Roth $\mathrm{C}$ model was implemented based on two climatic scenarios. The first scenario involves the storage of soil organic carbon if the long-term climate conditions continues (Present condition that marked with P) which in fact, includes the monthly mean precipitation and temperature observed at the local synoptic meteorological station of Mahallat over a 30-year statistical period from 1987 to 2017 and the second scenario included SOC stock under climate change condition (marked as $\mathrm{CCH}$ ). The climate change scenario was based on a study by Koochaki et al. (2007) [20] who predicted that between 2017 and 2050 due to climate change in Gal-Cheshmeh, annual precipitation would decrease $10.39 \%$ and average temperature would increase by $15.28 \%$ more than the region's long-term average values. Finally, SOC stock was simulated under a baseline scenario $(\mathrm{P})$ and a climate change scenario $(\mathrm{CCH})$ in vegetation treatments in the Gal-Cheshmeh region. Fig. 3 shows the flowchart of the methodology adopted in this study for determination of SOC.

\section{Results and Discussion}

Effect of Native Vegetation Conversion to Other Coverings of Gal-Cheshmeh Region on Changing SOC Stock Levels

Table 2 shows SOC stock measured for all vegetation treatments in September 2016. The rangeland treatment, which was considered as native vegetation of

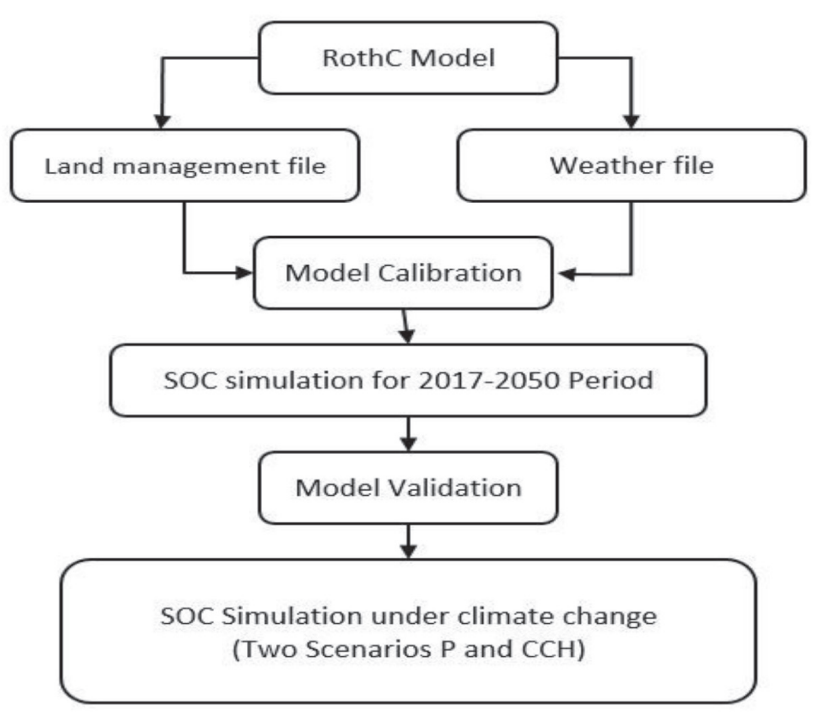

Fig. 3. Flowchart of the methodology. 
Table 2. Data of soil and vegetation cover in the treatments of Gal-Cheshmeh region.

\begin{tabular}{|c|c|c|c|c|c|c|c|c|}
\hline Treatment & $\begin{array}{c}\text { Bulk } \\
\text { density } \\
\left(\mathrm{gr} \mathrm{cm}^{-3}\right)\end{array}$ & $\begin{array}{c}\text { Sand } \\
(\%)\end{array}$ & $\begin{array}{c}\text { Silt } \\
(\%)\end{array}$ & $\begin{array}{c}\text { Clay } \\
(\%)\end{array}$ & $\begin{array}{c}\text { EC } \\
(\mathrm{ds} / \mathrm{m})\end{array}$ & $\begin{array}{c}\text { Initial total SOC } \\
\left(\text { Ton h }^{-1}\right)\end{array}$ & $\begin{array}{c}\text { DPM/RPM } \\
\text { Soil carbon } \\
\text { inputs } \\
\left(\text { Ton C ha }^{-1}\right)\end{array}$ \\
\hline Native Rangeland & 1.812 & 64.61 & 21.21 & 14.18 & 451.24 & $58.644(0.0)^{\mathrm{a}}$ & 0.67 & 2.8512 \\
\hline Restoration rangeland & 1.922 & 48.83 & 33.98 & 17.19 & 667.33 & $69.12(+17.86)$ & 0.67 & 3.2015 \\
\hline Cattle-grazed rangeland & 1.590 & 61 & 21 & 18 & 430.65 & $43.407(-25.98)$ & 0.67 & 2.0050 \\
\hline Cultivated rangeland & 1.874 & 56.04 & 25.68 & 18.28 & 2364.3 & $56.61(-3.47)$ & 1.44 & 2.7640 \\
\hline
\end{tabular}

a Percent of deviation in comparison with native vegetation (rangeland).

the region, was assumed to be in equilibrium state. The equilibrium state means that the carbon entering the soil through plant litter is equivalent to the carbon exiting the soil in $\mathrm{CO}_{2}$ form [23]. SOC stock in equilibrium state in rangeland treatment was 58.644 (Ton ha-1). By reviving the rangeland plant with species such as Atriplex canesence, Zygophyium atriplicoides, and Amygdalus scoparia in 2011, SOC stock increased from

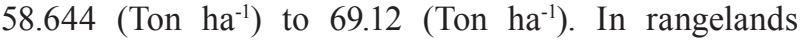
under cattle-grazing, SOC stock levels decreased from 58.644 (Ton ha-1) to 43.407 (Ton ha-1). Also, with the cultivation of barley with alternation of cucurbits and fallow lands in 2000 and cultivation of Rosa damascena in 2014, SOC stock levels decreased from 58.644 (Ton ha-1) to 56.61 (Ton ha' ${ }^{-1}$ ).

In general, SOC storage in the study area were increased in the restoration rangeland treatment and in cattle-grazed rangeland treatment and agricultural land compared to control rangeland, there was a decrease (Table 2). That vegetation change plays an important role in increasing SOC [3]. In the restoration of rangelands after 8 years (2009-2017), SOC storage increased by $17.86 \%$, due to the cultivation of rangeland plants such as Atriplex canesence, Zygophyiium atriplicoides, and Amygdalus scoparia. Also, SOC content in rangeland under severe cattle-grazing, decreased 25.98\% compared to control rangeland. In the agro-ecosystem, after 17 years (2000-2017), the amount of SOC decreased by $3.47 \%$ compared to control rangeland (Table 2). Increase in SOC reserves in the rangeland treatment restoration and enclosed rangeland indicates the successful management and restoration of rangeland operations in the Gal-Cheshmeh region. After 8 years of rangeland cultivation and enclosing operations, the reaction of SOC has been positive to this process. Restoration and enclosing of the rangelands, together, prevent soil erosion, thereby reducing SOC emissions to the atmosphere and help increase SOC reserves. Various researchers, have pointed out the positive effects of vegetation restoration on SOC reserves [6-7].

\section{The Effect of Climate Change Scenarios on Changes in SOC Stock Levels in Different Treatments}

Model outputs showed that during 33 years (2017 to 2050) SOC storage without climate change in the treatment of the control rangeland, restoration rangeland, severely cattle-grazed rangeland and agricultural land compared to 2017 will change $+0.79 \%$, $-9.29 \%,-11.28 \%, \quad-0.97 \%$, respectively (Table 3). Simulating the effect of climate change on SOC storage in different treatments, the model outputs showed that during 33 years (2017 to 2050) SOC storage in treatment of rangeland, restoration rangeland, cattle-grazed rangeland, and agricultural lands compared to 2017, will decrease by $6.28 \%, 16.09 \%, 13.12 \%$ and $7.28 \%$, respectively (Table 3 ). In the climate change scenario in the region, as the mean annual temperature increases by 2.67 degrees and the average precipitation decreases by $24.87 \mathrm{~mm}$, therefore with the reduction of rainfall in one hand and increased temperature in the other, consequently potential evapotranspiration in the region increases and the vegetation will gradually decrease and

Table 3. SOC Stock and its percentage change compared to 2017 in the different treatments under two scenarios of climate change in the Gal-Cheshmeh region.

\begin{tabular}{|c|c|c|c|c|c|}
\hline & & \multicolumn{2}{|c|}{ No Climate Change Scenario } & \multicolumn{2}{c|}{ Climate Change Scenario } \\
\hline Treatment & $\begin{array}{c}\text { SOC Stock in 2017 } \\
\left(\text { Ton ha }^{-1}\right)\end{array}$ & $\begin{array}{c}\text { SOC Stock in 2050 } \\
\left(\text { Ton ha }^{-1}\right)\end{array}$ & $\begin{array}{c}\text { Change compared } \\
\text { to 2017 }(\%)\end{array}$ & $\begin{array}{c}\text { SOC Stock in 2050 } \\
\left.\text { (Ton ha }^{-1}\right)\end{array}$ & $\begin{array}{c}\text { Change compared } \\
\text { to 2017 }(\%)\end{array}$ \\
\hline Native Rangeland & 58.644 & 59.11 & 0.79 & 54.96 & -6.28 \\
\hline Restoration rangeland & 69.12 & 62.70 & -9.29 & 58.00 & -16.09 \\
\hline Cattle-grazed rangeland & 43.407 & 38.51 & -11.28 & 37.71 & -13.12 \\
\hline Cultivated rangeland & 56.61 & 56.06 & -0.97 & 52.49 & -7.28 \\
\hline
\end{tabular}


diminish. Increasing temperatures will also increase carbon dioxide $\left(\mathrm{CO}_{2}\right)$ emissions and the decomposition of organic matter from soil and litter, and these factors will have a detrimental effect on SOC reserves. Also, these results are clearly visible in the RothC model in the scenario and climate change. Results of study in the Wisconsin region, northern center of the United States of America showed that among land use classes, wetlands had the highest SOC reserve (534 $\left.\mathrm{Mg} \mathrm{ha}^{-1}\right)$, and cultivated lands and shrubs, on average, had (44 $\mathrm{Mg} \mathrm{ha}^{-1}$ ) of SOC reserve [26].

Overall, the results showed that climate change in the Gal-Cheshmeh region, which would be associated with reduced rainfall and increased temperature, reduced soil carbon sequestration (SOC stock) in all treatments (Table 3). Temperature and precipitation, which are the most important climatic factors affecting plant productions, affect the quality and quantity of litter [27] as well as the microbial activity of decomposing plant residues [28]. With increasing temperature under climate change, the rate of decomposition of soil organic matter is increased, which increases soil organic carbon loss [29]. As a result, modeling of soil carbon sequestration rates in soils under different treatments in the region showed a decreasing trend (Fig. 4). In a study conducted in Andalusia (southern Spain), while using the Roth $\mathrm{C}$ model during a 51year period, reported SOC sequestration rates for different soil types and vegetation, and provided basic information on carbon emissions, soil organic carbon modeling, and reduction scenarios related to land use change processes for future studies [10]. Also in studies in Bajgah region (Iran) using Roth $\mathrm{C}$ model showed that by simulating the effect of climate change on SOC stock dynamics in rangeland treatments, almond tree story, rangelands under the cedar tree story, cedar and almond trees during 36 years (2014 to 2050), SOC stock in all treatments will decrease compared to the year 2014 [6]. The simulation results showed that climate change would decrease SOC stock in the studied treatment of Gal-Cheshmeh region from $6.28 \%$ up to $16.09 \%$, and the rate of SOC stock decrease would be almost the same in all treatments (Table 3). The SOC partitioning procedure has potential, and the measured carbon pools more reasonably reflected the real environmental conditions than the modelled pools. In response to increasing temperature and summer drought in the future (2021-2060), the SOC will tend to decrease for temperate grassland in Ireland by between 2 and $6 \%$ and suitable grassland land management practices therefore should be examined to limit this loss [30]. The decrease in SOC stock was lower in rangelands and farmland treatments in Gal-Cheshmeh area than in other treatments (Table 3), which is probably due to the low quality of litter returned to soil in the rangeland treatments, so that the ratio of decomposable plant material to resistant plant material (litter quality) was lower in farmland treatments compared to rangeland treatments (Table 2) and plant material decomposed later. Stated that improving rangeland management practices and converting from farmland to rangeland would improve soil carbon reserves [31]. Reported that

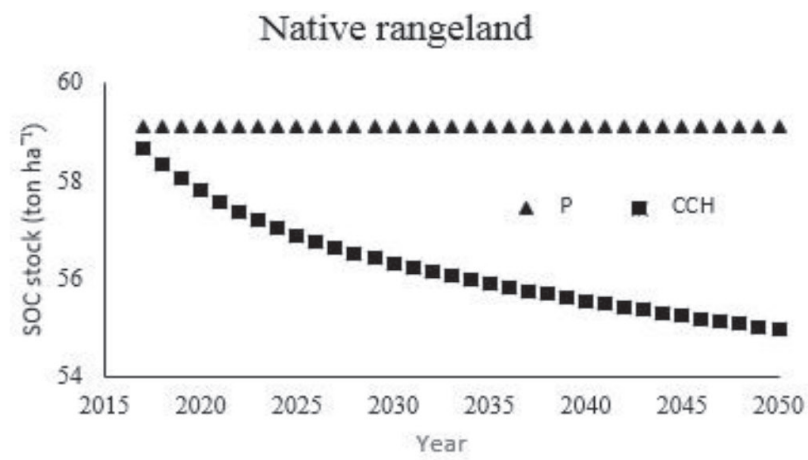

Cattel-grazed rangeland

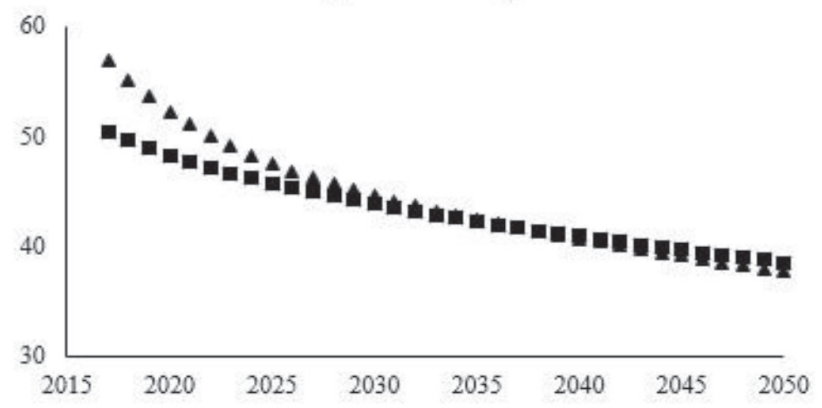

Restoration rangeland

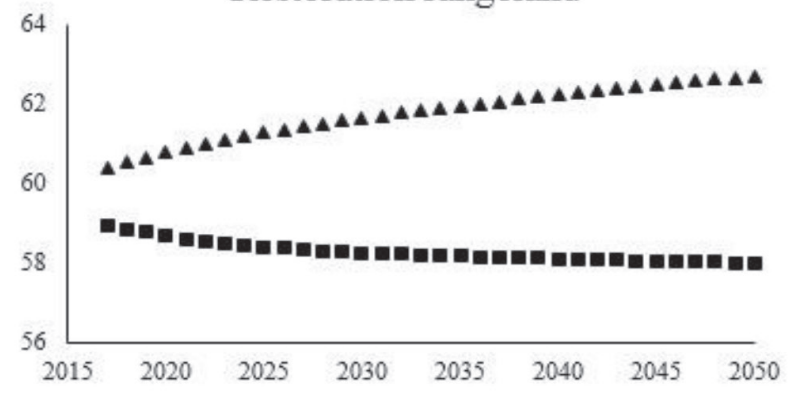

Cultivated rangeland

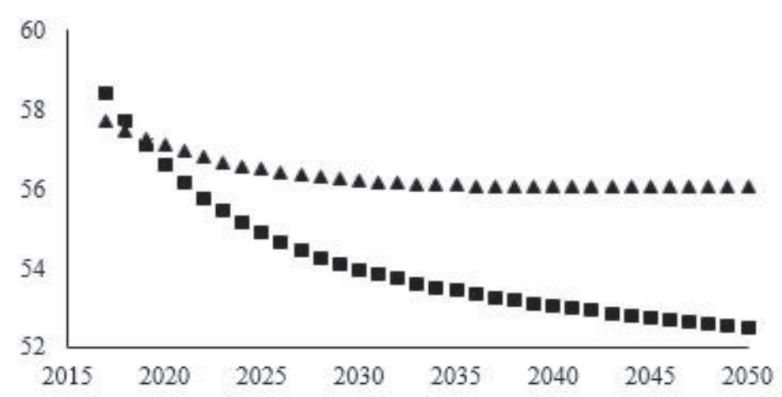

Fig. 4. SOC stock in two climate change scenarios; Present condition $(\mathrm{P})$ and Climate change condition $(\mathrm{CCH})$ in the different vegetation treatments in the Gal-Cheshmeh region. 
in climate change, precipitation determines soil carbon changes. However, they considered soil temperature changes to be a more effective factor on soil carbon storage on the global scale [32]. Temperature is the first effective factor in the development of known microbial processes in the soil and even has a dramatic effect on vegetation changes, so that in theory one degree of increase in average annual temperature would be equivalent to $200 \mathrm{~km}$ advancement of habitat areas towards Polar Regions [33-34]. Several factors may contribute to an increase in land surface temperature, such as an increase in residential areas, change in the cropping pattern and overall global climate change [35]. The agroforestry alone cannot be sustained, and hence, it has to be integrated with land productivity enhancement, natural resource management, climate change adaptation, and livelihood support in addition to tree plantation in agricultural lands [36]. Therefore, it seems that changing the ecosystem temperature regime in climate change conditions will have significant effects on the carbon budget of the ecosystem by affecting the amount and speed of soil degradation reactions as well as the plant composition and diversity of the environment. But in the present research, because the amount of SOC stock changes in only one area has been studied, and with the climate scenarios using the meteorological data of one deployed meteorological station, it is practically impossible to investigate the independent relationship between precipitation gradient and temperature with the amount of SOC stock changes.

\section{Conclusion}

With the simulation results of the RothC model, we can achieve useful information in relation to land cover and future climate changes. Our results indicated the RothC model can adequately predict the SOC stocks at arid rangelands. The conversion of a prior natural rangeland to Restoration of rangeland plantations resulted in a sharp increase in the SOC stock, but with a lower effect to be attributed to future climate change. In the Mahallat region, the effects of land use management and land use changes on SOC stock in rangelands treatment compared to restoration rangeland (control) of the region, is increasing and in other land uses including rangeland under intensive cattlegrazing and agro-ecosystem, it has been decreasing. So rangelands restoration and correction operations, including cultivation of rangeland plant such as of Atriplex canesence, Zygophyiium atriplicoides, and Amygdalus scoparia in the Mahallat area, which is exposed to desertification, will undoubtedly be a positive step in reducing $\mathrm{CO}_{2}$ content of the atmosphere. On the other hand, due to the destructive effects of severe cattle-grazing, especially on inclined slopes that cause poor vegetation cover, increased surface runoff and soil erosion, indigenous Amygdalus species can control soil erosion by reducing emission and increasing atmospheric carbon sequestration in line with the goals of the Markazi Province, Iran. The development of cultivation of the aforementioned species is also of economic value (generated from the fruit sale and the use of branches for the production of crafts) for local communities. The simulation results of the Rothamsted model showed the reduction of soil carbon sequestration (SOC stock) in all treatments of the Mahallat region during the climate change scenario. Our results point out that the use of a simulation approach is reasonable and cost-effective in comparison with long-term monitoring requiring expensive measurements. Simulation models combined with SOC inventory data can be considered as the most advanced tools of reporting and management planning.

\section{Acknowledgements}

We thank Forests, Range and Watershed Management Organization, Iran and Department of Natural Resources and Watershed Central Province, for constructive suggestions.

\section{Conflict of Interest}

The authors declare no conflict of interest.

\section{References}

1. KEESSTRA S.D., BOUMA J., WALLINGA J., TITTONELL P., SMITH P., CERDÀ A., MONTANARELLA L., BARDGETT R.D. The significance of soils and soil science towards realization of the United Nations Sustainable Development Goals. Soil, 2016. Doi: 10.5194/soil-2-111-2016.

2. BREVIK E.C., CERDÀ A., MATAIX-SOLERA J., PEREG L., QUINTON J.N., SIX J., VAN OOST K. The interdisciplinary nature of SOIL. Soil, 1 (1), 117, 2015. Doi: 10.5194/soil-1-117-2015.

3. YIGINI Y., PANAGOS P. Assessment of soil organic carbon stocks under future climate and land cover changes in Europe. Science of the Total Environment, 557, 838, 2016. Doi: 10.1016/j.scitotenv.2016.03.085.

4. SOLANGI G.S., SIYAL A.A., SIYAL P. Spatiotemporal Dynamics of Land Surface Temperature and its impact on the Vegetation. Civil Engineering Journal, 5 (8), 1753, 2019. Doi: 10.28991/cej-2019-03091368.

5. XIN Z., QIN Y., YU X. Spatial variability in soil organic carbon and its influencing factors in a hilly watershed of the Loess Plateau, China. Catena, 137, 660, 2016. Doi: 10.1016/j.catena.2015.01.028.

6. AZAD B., AFZALI S.F., GHANBARIAN G.A. Modeling the effect of vegetation conversion and climate change on SOC stock dynamics in a complex ecosystem. Soil Management and Sustainable Production, 2018. Doi: 10.1017/9781107339217.2.

7. MUÑOZ-ROJAS M., DORO L., LEDDA L., FRANCAVIGLIA R. Application of CarboSOIL model to predict the effects of climate change on soil organic carbon 
stocks in agro-silvo-pastoral Mediterranean management systems. Agriculture, Ecosystems \& Environment, 202, 16, 2015. Doi: 10.1016/j.agee.2014.12.014.

8. MUÑOZ-ROJAS M., ABDELMABOD S.K., ZAVALA L.M., DE LA ROSA D., JORDÁN A. Climate change impacts on soil organic carbon stocks of Mediterranean agricultural areas: a case study in Northern Egypt. Agriculture, ecosystems \& environment, 238, 152, 2017. Doi: 10.1016/j.agee.2016.09.001.

9. BATJES N.H. Total carbon and nitrogen in the soils of the world. European journal of soil science, 65 (1), 10, 2014. Doi: 10.1111/j.1365-2389.1996.tb01386.x.

10. MUÑOZ-ROJAS M., JORDÁN A., ZAVALA L.M., DE LA ROSA D., ABD-ELMABOD S.K., ANAYA-ROMERO $M$. Impact of land use and land cover changes on organic carbon stocks in Mediterranean soils (1956-2007). Land Degradation \& Development, 26 (2), 179, 2015. Doi: 10.1002/ldr.2194.

11. ABDALlA M., HASTINGS A., CHADWICK D.R., JONES D.L., EVANS C.D., JONES M.B., SMITH, P. Critical review of the impacts of grazing intensity on soil organic carbon storage and other soil quality indicators in extensively managed grasslands. Agriculture, ecosystems and environment, 253, 62, 2018. Doi: 10.1016/j. agee.2017.10.023.

12. KOWALSKA A., PAWLEWICZ A., DUSZA M., JASKULAK M., GROBELAK A. Plant-soil interactions in soil organic carbon sequestration as a restoration tool. In Climate Change and Soil Interactions, 663, 2020. Doi: 10.1016/b978-0-12-818032-7.00023-0.

13. YUE C., CIAIS, P. BASTOS A., CHEVALLIER F., YIN Y., RÖDENBECK C., PARK T. Vegetation greenness and land carbon-flux anomalies associated with climate variations: a focus on the year 2015. Atmospheric Chemistry and Physics, 17 (22), 13903, 2017. Doi: 10.5194/ acp-17-13903-2017.

14. VAN KOOTEN G.C. Climate Change and Agriculture (No. 2020-01), 2020. Doi: 10.7551/mitpre ss/9780262034876.003.0005.

15. FRANCAVIGLIA R., COLEMAN K., WHITMORE A.P., DORO L., URRACCI G., RUBINO M., LEDDA L. Changes in soil organic carbon and climate change Application of the RothC model in agro-silvo-pastoral Mediterranean systems. Agricultural Systems, 112, 54, 2012. Doi: 10.1016/j.agsy.2012.07.001.

16. SRINIVASAN V., SANDERSON M., GARCIA M., KONAR M., BLÖSCHL G., SIVAPALAN M. Prediction in a socio-hydrological world. Hydrological Sciences Journal, 62 (3), 338, 2017. Doi: 10.1080/02626667.2016.1253844.

17. PARTON W.J., OJIMA D.S., COLE C.V., SCHIMEL D.S. A general model for soil organic matter dynamics: sensitivity to litter chemistry, texture and management. Quantitative modeling of soil forming processes, 39, 147, 1994. Doi: $10.2136 /$ sssaspecpub39.c9.

18. FRANCAVIGLIA R., COLEMAN K., WHITMORE A.P., DORO L., URRACCI G., RUBINO M., LEDDA L. Changes in soil organic carbon and climate change Application of the RothC model in agro-silvo-pastoral Mediterranean systems. Agricultural Systems. 112, 48, 2012. Doi: 10.1016/j.agsy.2012.07.001.

19. FOROUZANGOHAR M., SETIA R., WALLACE D.D., NITSCHKE C.R., BENNETT L.T. Predicted consequences of increased rainfall variability on soil carbon stocks in a semiarid environment. Climate Research, 67 (1), 61, 2016. Doi: 10.3354/cr01356.
20. KOOCHEKI A., NASSIRI M., KAMALI A.G.H. Climate indices of Iran under climate change. j. Iran. Field Crop RES, 5, 143, 2007. Doi: 10.20944/preprints 201705.0089. v2.

21. SIMO I., SCHULTE R., O'SULLIVAN L., CREAMER R. Digging deeper: Understanding the contribution of subsoil carbon for climate mitigation, a case study of Ireland. Environmental Science and Policy, 98, 61, 2019. Doi: 10.1016/j.envsci.2019.05.004.

22. COLEMAN K., JENKINSON D.S. A model for the turnover of carbon in soil, Model description and windows users guide. Rothamsted Research: Harpenden, UK. 2008. Doi: 10.1007/978-3-642-61094-3_17.

23. TORNQUIST C.G., MIELNICZ̄UK J., CERRI C.E. P. Modeling soil organic carbon dynamics in Oxisols of Ibirubá (Brazil) with the Century Model. Soil and Tillage Research, 105, 33, 2009. Doi: 10.1016/j.still.2009.05.005.

24. MAC DICKEN K.G. A Guide to Monitoring Carbon Storage in Forestry and Agroforestry Projects. Winrock International Institute for Agricultural Development, Forest Carbon Monitoring Program. 91, 1997.

25. FALLOON P., SMITH P., COLEMAN K., MARSHALL S. Estimating the size of the inert organic matter pool from total soil organic carbon content for use in the Rothamsted carbon model. Soil Biology and Biochemistry, 30, 1211, 1998. Doi: 10.1016/s0038-0717 (97)00256-3.

26. ADHIKARI K., OWENS P.R., LIBOHOVA Z., MILLER D.M., WILLS S.A., NEMECEK J. Assessing soil organic carbon stock of Wisconsin, USA and its fate under future land use and climate change. Science of the Total Environment, 667, 833, 2019. Doi: 10.1016/j. scitotenv.2019.02.420

27. PENNER J.F., FRANK D.A. Litter De-composition in Yellowstone Grasslands: The Roles of Large Herbivores, Litter Quality, and Climate. Ecosystems, 22 (4), 929, 2019. Doi: 10.1007/s10021-018-0310-9.

28. LIANG X., YUAN J., YANG E., MENG J. Responses of soil organic carbon decomposition and microbial community to the addition of plant residues with different C: N ratio. European Journal of Soil Biology, 82, 50, 2017. Doi: 10.1016/j.ejsobi.2017.08.005.

29. NAIPAL V., CIAIS P., WANG Y., LAUERWALD R., GUENET B., VAN OOST K. Global soil organic carbon removal by water erosion under climate change and land use change during AD 1850-2005. Bio geosciences, 4459, 2018. Doi: $10.5194 /$ bg-2017-527-rc2.

30. XU X., LIU W., KIELY G. Modeling the change in soil organic carbon of rangeland in response to climate change: Effects of measured versus modeled carbon pools for initializing the Rothamsted Carbon model. Agriculture, Ecosystems and Environment, 140, 372, 2011. Doi: 10.1016/j.agee.2010.12.018.

31. CONANT R.T., CERRI C.E., OSBORNE B.B., PAUSTIAN K. Rangeland management impacts on soil carbon stocks: a new synthesis. Ecological Applications, 27 (2), 668, 2017. Doi: 10.1002/eap.1473.

32. FALLOON P., JONES C.D., CERRI C.E., AL-ADAMAT R., KAMONI P., BHATTACHARYYA T., EASTER M., PAUSTIAN K., KILLIAN K., COLEMAN K., MILNE E. Climate change and its impact on soil and vegetation carbon storage in Kenya, Jordan, India and Brazil. Agriculture, Ecosystems \& Environment, 122, 114, 2007.

33. LAL R. Soil carbon sequestration to mitigate climate change. Geoderma, 123, 2004. Doi: 10.1016/j. geoderma.2004.01.032. 
34. BECKLIN K.M., ANDERSON J.T., GERHART L.M., WADGYMAR S.M., WESSINGER C.A., WARD J.K. Examining plant physiological responses to climate change through an evolutionary lens. Plant physiology, 172 (2), 635, 2016. Doi: 10.1104/pp.16.00793.

35. OO H.T., ZIN W.W., KYI C.C.T. Assessment of Future Climate Change Projections Using Multiple Global
Climate Models. Civil Engineering Journal, 5 (10), 2152, 2019. Doi: 10.28991/cej-2019-03091401.

36. ARYAL K., THAPA P.S., LAMICHHANE D. Revisiting Agroforestry for Building Climate Resilient Communities: A Case of Package-Based Integrated Agroforestry Practices in Nepal. Emerging Science Journal, 3 (5), 303, 2019. Doi: 10.28991/esj-2019-01193. 